DOI: https://doi.org/10.34069/AI/2021.37.01.9

\title{
Application fields of gamification
}

\section{Сфери застосування гейміфікації}

Received: December 20, 2020

\section{Abstract}

In the modern period of universal consumer and entertainment psychology of society, interest in gamification is growing. Game components penetrate into all spheres of activity: business, banking, education and even medicine - common trainings, quests aimed at mastering certain skills.

The method of typology, aimed at finding stable features and properties of the object under study. Content analysis was involved, in particular, resources with gamified elements were monitored for automated information retrieval (content monitoring).

In the course of the research we came to the conclusion that gamification has a significant impact on the life of modern man. The market of gamified technologies is actively developing in Ukraine and the world.

Gamification allows the rational use of available resources, so that as a result all parties achieve the goal, but its use should be treated with caution so as not to exacerbate existing contradictions or, conversely, not to demotivate. That is why it is so important to be critical of the use of game elements in each of the spheres, to realize and distinguish the useful potential of the game from the game as an end in itself, which can adversely affect mental and physical health, self-realization in society.
Accepted: February 6, 2021

\begin{tabular}{|c|}
\hline \\
\hline \\
\hline \\
\hline \\
\hline \\
\hline \\
\hline \\
\hline \\
\hline \\
\hline \\
\hline $\begin{array}{r}\text { Written by: } \\
\text { Nadiia Figol }^{32}\end{array}$ \\
\hline https://orcid.org/0000-0002-2503-7243 \\
\hline Tetiana Faichuk ${ }^{33}$ \\
\hline https://orcid.org/0000-0001-6357-8158 \\
\hline Iryna Pobidash ${ }^{34}$ \\
\hline https://orcid.org/0000-0001-9876-2203 \\
\hline Olga Trishchuk ${ }^{35}$ \\
\hline https://orcid.org/0000-0002-4009-8749 \\
\hline $\begin{array}{r}\text { Vasyl Teremko }^{\mathbf{3 6}} \\
\text { https://orcid_org/0000-0002-9045-7674 }\end{array}$ \\
\hline
\end{tabular}

Резюме

У сучасний період загальної споживацької та розважальної психології суспільства зростає інтерес до гейміфікації. Ігрові компоненти проникають у всі сфери діяльності: бізнес, банківську справу, освіту і навіть медицину загальні тренінги, квести, спрямовані на оволодіння певними навичками.

У роботі застосовано метод типології, спрямований на пошук стійких ознак та властивостей досліджуваного об'єкта. Метод контент-аналізу залучено, зокрема, для моніторингу ресурсів 3 гейміфікованими елементами та для автоматизованого пошуку інформації (моніторинг вмісту).

В ході дослідження ми дійшли висновку, що гейміфікація має значний вплив на життя сучасної людини. Ринок ігрових технологій активно розвивається в Україні та світі.

Гейміфікація дозволяє раціонально використовувати наявні ресурси, щоб в результаті всі сторони досягли мети, але до їі використання слід ставитися обережно, щоб не загострити наявні суперечності або, навпаки, не демотивувати. Ось чому так важливо критично ставитися до використання ігрових елементів у кожній зі сфер, усвідомлювати та відрізняти корисний потенціал гри від гри як самоцілі, яка може негативно вплинути на психічне та фізичне здоров’я, самореалізацію в суспільстві.

\footnotetext{
${ }^{32}$ National Technical University of Ukraine. Igor Sikorsky Kyiv Polytechnic Institute, Ukraine.

${ }^{33}$ O. O. Potebnia Institute of Linguistics of the National Academy of Sciences of Ukraine, Kyiv, Ukraine.

${ }^{34}$ National Technical University of Ukraine. Igor Sikorsky Kyiv Polytechnic Institute, Ukraine.

${ }^{35}$ National Technical University of Ukraine. Igor Sikorsky Kyiv Polytechnic Institute, Ukraine.

${ }^{36}$ Taras Shevchenko National University of Kyiv, Ukraine.
} 
Key Words: games, gamification, gamified content, motivation, user.

\section{Introduction}

In modern age of entertainment psychology, the interest in gamification is growing every year. Game components are penetrating into all fields of activity, and are especially noticeable in education and manufacturing: widespread trainings, quests aimed at mastering certain skills. Realizing the importance of social interaction transition to new forms, we turned to the newest method - gamification - which has a high potential for use, determining the relevance of our paper.

The aim of the article is to define the fields of application of gamification, to study the peculiarities of its functioning, and to clarifythe role of gamification as a phenomenon in the era of global world changes.

\section{Methodology}

The methods applied in the research include general scientific methods of analysis and synthesis, which allowed identifying specific examples of gamification implementation, establishing criteria for its effectiveness, finding out the advantages and disadvantages of gamification as a phenomenon, identifying the possible risks.

Descriptive methods, in particular the method of typology, focused on the search for stable features and properties of the object under research, were applied. This method enabled to determine the features of gamified components in different spheres. The method of typological analysis allowed analyzing and comparing the effectiveness and efficiency of gamification in different areas of human life, determining the general trends and prospects for development.

We involved content analysis as a method of collecting data about the phenomenon or process under research. Resources with gamified elements were monitored for automated search of information (content monitoring). The use of this type of content analysis is driven by the need for systematic tracking of trends and processes in a constantly updated information environment.

The article involves Case Study that is a method of qualitative research in the social sciences, which includes the study of a single social object (situation, event) in order to make sense
Ключові слова: ігри, гейміфікація, гейміфікований контент, мотивація, користувач.

of a broad class of similar cases (class of events). In the context of this article it is a research of the spheres of application of gamification for generalized interpretation of this phenomenon in the age of global world changes.

\section{Literature review}

The concept and processes of gamification today are widely researched by both foreign and Ukrainian scientists. Among foreign studies we single out the following aspects of research: Nick Pelling (was one of the first to apply the term "gamification") (Pelling, 2019); G. Zichermann (was the first to explore the use of game elements in non-game environment) (Zichermann, 2011); R. Bartle (proposed the classification of players to be taken into account for effective gamification implementation) (Bartle, 2004); E. J. Kim (investigated the conceptual apparatus and main features of gamification) (Kim, 2010); K. Kapp (explored the conceptual apparatus and basic features of gamification) (Kapp, 2012); K. Werbach and D. Hunter (distinguished between internal and external gamification) (Werbach and Hunter, 2012); K. Huotari and J. Hamari (compared the psychological effects of influence with game mechanics) (Huotari and Hamari, 2012); D. Clark (investigated the impact of game effects on motivation in learning) (Clark, 2006); I. Kostikova et al. (different aspects of the problem using games for education (gamification) were researched) (Kostikova et al., 2019), V. Sánchez Castillo et al. (the implementation of audiovisual aids (video games) in teaching and learning of the subject) (Sánchez Castillo, 2016), F. Groh (identified gamification as an acceptable method for applying game design in a non-game context) (Groh, 2012).

Among national studies we should mention the works of A. Mostova (researching the concept of gamification and its role in marketing) (Mostova, 2018); A. Bezchotnikova (studying the application of gamification to solve advertising and PR-tasks) (Bezchotnikova, 2016); G. Sereda (analysis of gamification in personnel management) (Sereda, 2017); N. Holovko (the role of game technologies as a means of activating cognitive activity of students) (Holovko, 2015); L. Sergeeva 
(coverage of gamification from the point of view of competitive aspect, is a key to competition put in the basis of business) (Sergeeva, 2019).

Besides scientific articles on gamification, it is worth mentioning webinars on this topic: S. Nasyrova suggests using game elements in business (Nasyrova, 2019).

\section{Results and Discussion}

The main value of gamification is to change the behavior of a person or audience as a whole, so it is primarily used to improve the effectiveness of activities in various processes.

Gamification is now used in all areas of human life. Its advantage is regarded as the principle of instant feedback: a large goal is divided into many small ones, and the user always notices his or her even smallest progress.

By structure, the game includes internal and external motivation to continue the state of involvement. In the game you can not only win or lose, but also play again that provides unlimited time involvement potential. A distinctive feature of games includes the incentives and goals set for the participant. No text is capable of providing such a high level of interactivity, and does not require decisionmaking or instant feedback.

Gamification is effective for visual recognition of achievements, organization of competitions within the community, and design of learning content. It is a powerful tool for impacting human activity through the use of motivation and human involvement in the process.

During the research we have identified the main fields of application of gamification: business, banking, education and science, marketing, medicine.

Business. Gamification is capable of transforming business models, as modern companies continue to invest in it, using game methods to attract customers, introduce specific areas of business, increase customer loyalty, train employees, motivate workers, promote personal development, and manage innovation.

Gamification in business is primarily focused on motivating the staff, attracting employees to the company's processes and thereby increasing their productivity. The implementation mechanism is a set of game techniques, for which any external form can be developed: a football championship, a race, and so on.

To improve efficiency, modern businesses and corporations are creating special software or the latest gamified devices. For example, in 2018, Amazon developed trackers for warehouse workers. In addition to collecting movement information, these devices analyze proper work and send the data to a ranking list. Each device has a tactile transmitter that captures the worker's movements, evaluates their correctness and provides feedback, by vibrating if the actions are incorrect. As a result, such gadgets have improved discipline and contributed to the productivity of the personnel.

Researching the use of gamification in business and human resource management, S. Nasyrova singles out a number of tools. Gamification as a tool of adaptation programs for new employees includes a system of board games, with the help of which new employees are introduced to the values of the company, features of work, rules of communication with customers (Nasyrova, 2019). In particular, Deloitte created a gamebased algorithm for new employees: newcomers must create teams, get acquainted online with the company's privacy policy and rules. Then each of the participants is supposed to answer some questions, and other team members are allowed to help and prompt. Such collective work is aimed at forming a friendly team.

Gamification as a tool of personnel motivation implies "internal ratings, systems of badges, achievements and awards" (Nasyrova, 2019). For example, Ukrainian Multiplex cinema chain offers its employees rewards for the successful plan completion: in addition to salary, an employee can get free tickets to a movie show. Sushiya adheres to a similar system, as it provides special discount coupons for employees to visit various restaurants.

An example of gamification as a tool for improving the quality of corporate training is Professional Skills Training program, which turned the e-learning system into a practical gamified management project. During the learning process in the application the user has to solve certain typical problems, which become more complicated with each level. While playing the game, learners receive "support" tutorial hints and experience - earned points for the successful solution of a problem. The aim of the game is to earn merit badges on each level, as well as to collect points. 


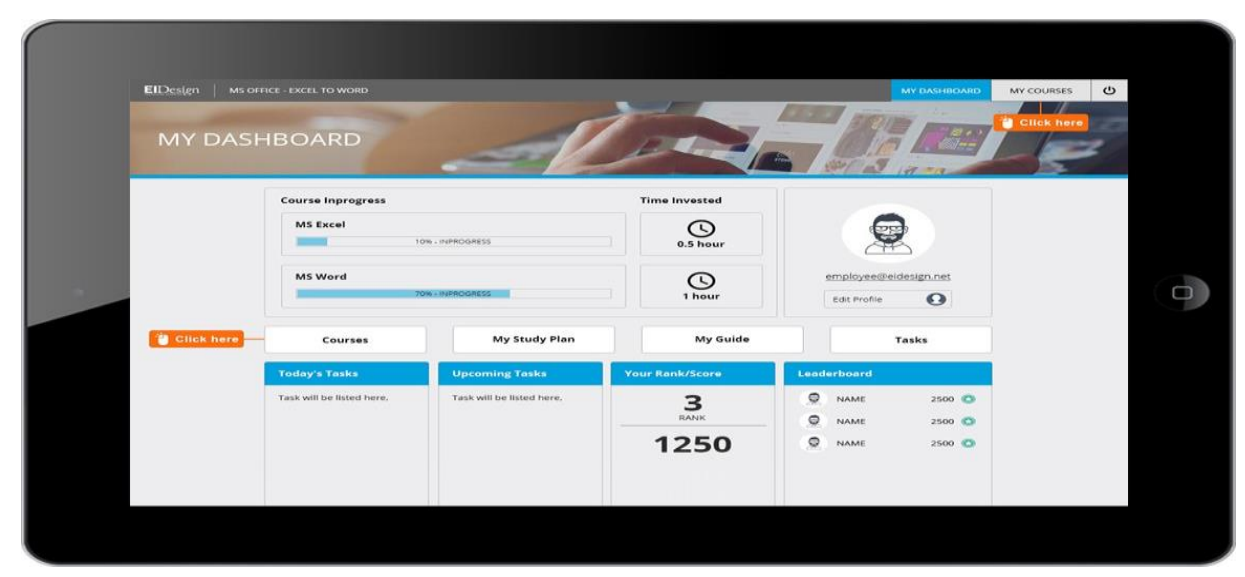

Fig. 1. The home screen of achievements in the Professional Skills Training App. Photo: prmac.com URL: https://prmac.com/

The experience of gamification projects in different companies proves that gamification becomes an effective instrument of corporate culture and personnel motivation system, ensures involvement of a hired employee in the common cause.

Banking. By using gamification in banking, a bank can focus on the specific needs of its customers. Applications in this area are designed primarily to attract the customer, but their format should be very discreet at the same time. Gamification draws attention and improves the level of involvement, but its excess may create a feeling of carelessness and insecurity of the financial structure. Banks are now practicing game mechanics and gaining experience to motivate people to use credit cards and open deposit accounts.

An example of gamification in banking is the Monobank app. By downloading the app to the mobile phone and taking a picture of the necessary documents in it, the client can quickly get a card. In addition to the card itself and the pin code for it, the envelope contains stickers or postcards (extra bonuses).

In 2018, a special deposit "Sports" was added to the bank's functionality. Under the terms, the client had to walk 10,000 steps a day to increase the deposit rate by 5\%. Walking and running can be done on a treadmill in the gym, as well as outdoors or in the park. Activity is measured using Apple Health or Google Fit, as well as devices and apps that sync with them: Mi Fit, Runkeper, Strava, Garmin, and others. Steps added manually will not be taken into account. The Monobank initiative was successful for several reasons: 10,000 steps is the rate of activity per day recommended by the WHO, money is a good incentive to fulfill it; an element of competition with friends has been involved in the motivation.
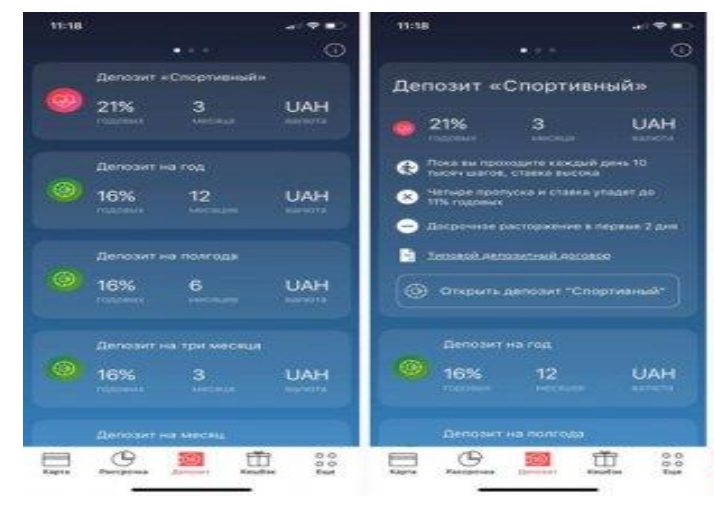

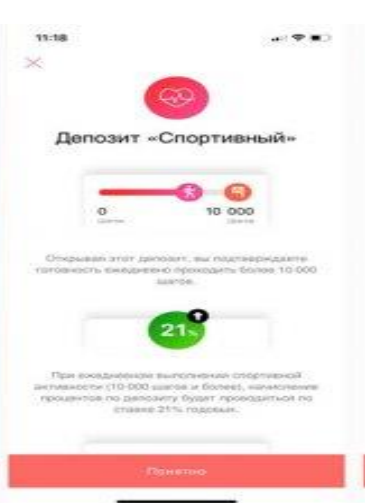

Deposit.

Photo: Monobank.

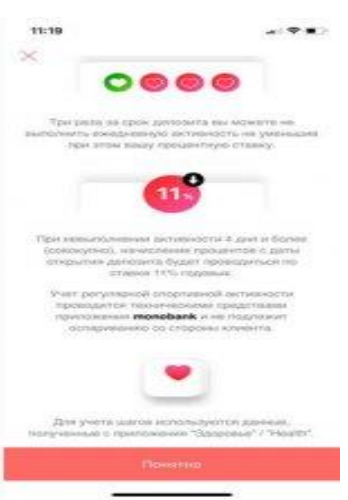

"Sports"

URL: https://www.monobank.ua/dashboard?utm_source=google\&utm_medium=cpc\&utm_campaign=search _brand_promodo 


\section{(2) AMAZONMA}

Despite a number of positive features provided by gamification in the banking industry (accessibility, simplification of banking operations), game elements simultaneously carry a hidden threat to the consumer. In fact, the game requires actions, and the actions leave digital data. A professional approach to deciphering this data enables banks to get a better understanding of their customers, gives a truthful overview of user activity and the level of their interest in banking services. And it is no longer about bonuses, badges or coins, but about valuable analytical data, expanded customer base and attractive image.

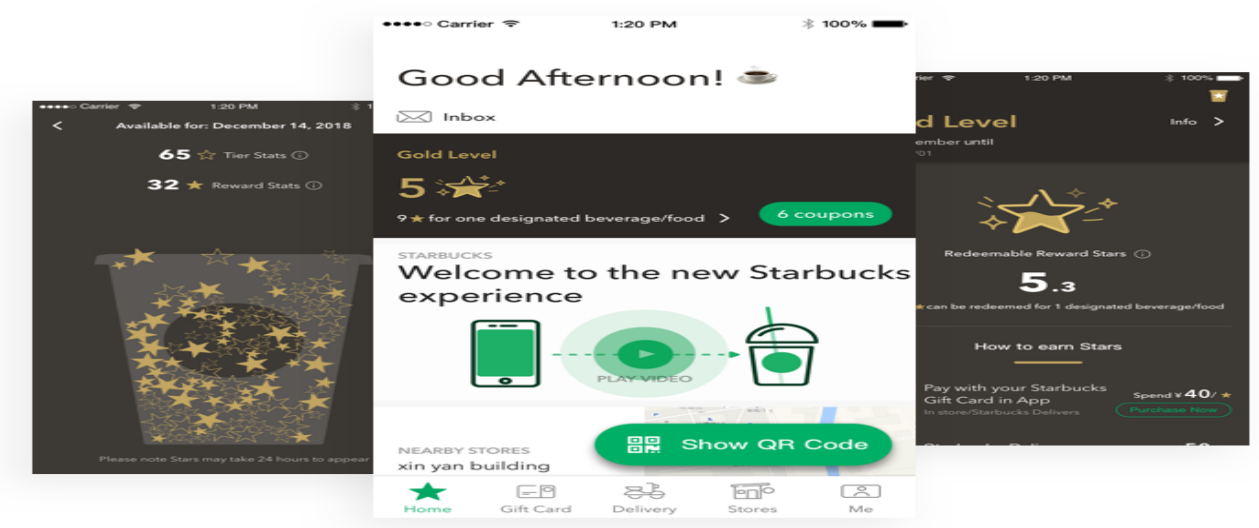

Fig. 3. An example of Starbucks App interface. Photo: stabucks.com. URL: https://www.starbucks.com/

A system with several levels was also developed: after collecting a certain number of points, the customer moves up a level. New bonuses were introduced respectively with each new level - an extra cup of coffee, a gift for a birthday or Christmas. Due to this approach the company managed to become one of the most popular coffeehouse chains in the world.
Marketing. The application of gamification in marketing is definitely a promising means of attracting customers. Gamification tools are appropriate to use in customer loyalty programs. In 2010 Starbucks introduced Foursquare badges to users who registered in different places and offered discounts for those who visit a certain outlet more frequently. The Starbucks game was implemented with the help of a mobile app. The customer has the ability to download a program to his or her phone that awards points for each company product purchased.
Gamification of the sales process increases brand awareness and confidence. Managers can engage the audience with traditional techniques: systems of accumulation, incentives or prizes, as well as use more non-typical ways to attract consumers. For example, the Swedish company IKEA developed an app with augmented reality technology. The store's products can be projected into your own space online with the help of technology (a digitized catalog).

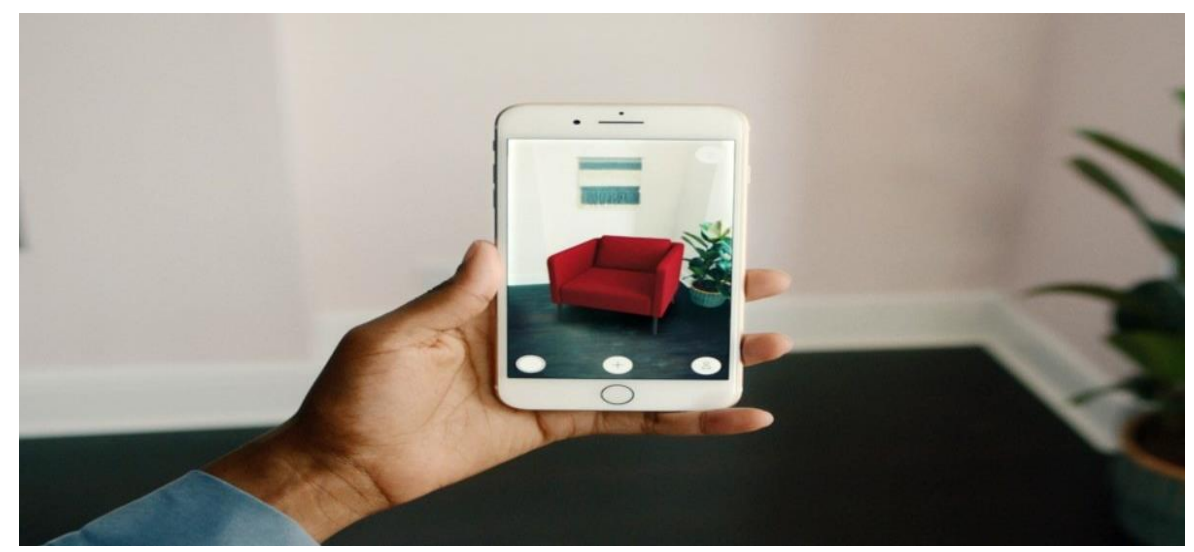

Fig. 4. Example of integrating IKEA products with an AR application. Photo: novator.io URL: https://novator.io/novosti/v-ikea-place-teper-mozhno-virtualno-obstavit-komnatu-tseloj-kollektsiejmebeli 
Using this app, people who are involved in renovations can not only think through the stylistic ideas and choose the necessary items, but also have fun with the game process of selection.

There are a lot of gamified apps available. In particular, the Pink Nation program from the popular Victoria's Secret brand was one of the first to implement gamified interaction between a clothing brand and a customer. Each week the program asked users to search for certain letters of the user's name among the products on the website or in retail stores. After a successful search, customers had to take a photo confirmation and receive a discount or prize.

The popular job search network LinkedIn is using gamification-based "hooks". Every time after adding new information to the profile the accuracy indicator of the personal page rises, but does not reach $100 \%$. The developers of the site have resorted to psychological techniques where an incomplete action affects users, encourages them to add more information about themselves, photos and texts, and the involvement rates on the site remain stable.

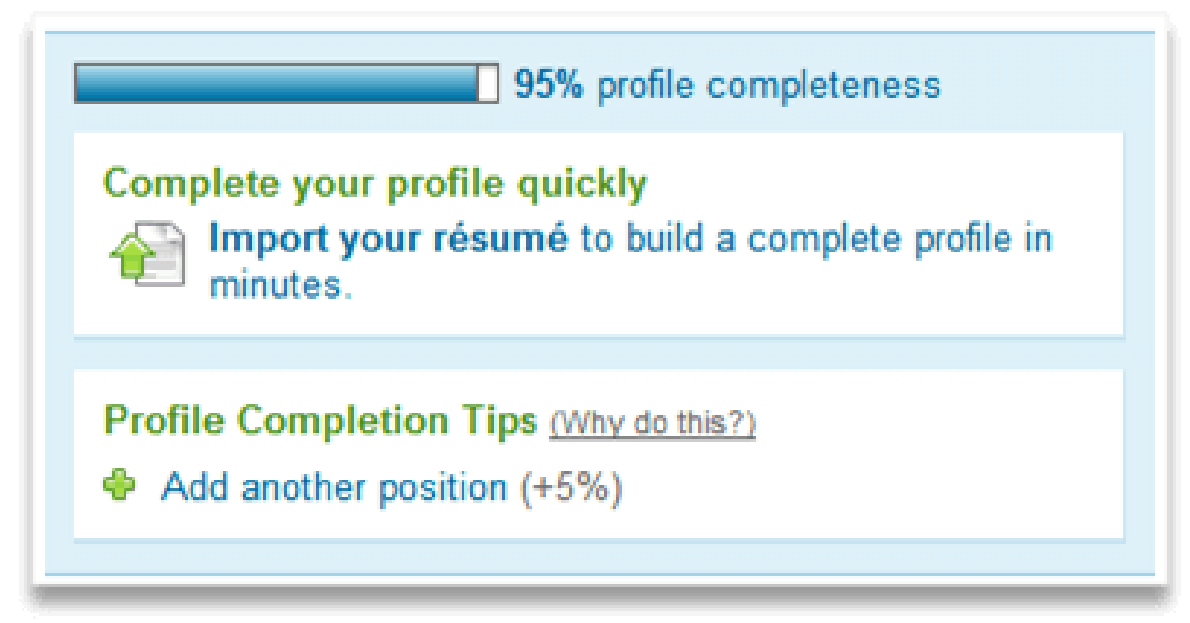

Fig. 5. The level of filling a personal account on the professional social network LinkedIn. Photo: LinkedIn. URL: https://www.linkedin.com/feed/

Other elements of attraction include constant LinkedIn email reminders: sending suggestion letters to review individual contacts, to expand the base on the platform, newsletters about profile revisions, achievements or events of other participants. A separate feature of the platform that seems dangerous to us is the import of a user's address book that is uploaded

to LinkedIn servers and used to organize contacts in LinkedIn and offer relevant connections. Thus, by obtaining additional personal data, LinkedIn has the opportunity to scrutinize its user thoroughly and deeply.

Health. Health-oriented companies resort to gamification to attract people's attention to their own well-being or to teach certain useful habits. The game format contributes to faster acquisition of knowledge on healthy lifestyles; a particular effect has been recorded in the younger consumer group. For example, a special toothbrush "Playbrush" with several sensors that send information to a smartphone has been developed. The program allows you to track the proper brushing and its effectiveness. But the main benefit for children is the collection of points for regular oral brushing.

The augmented reality role-playing video game "Pokemon Go" encourages people to go out, travel around the area searching and catching Pokemons, and communicate with other players. In this way, it overcomes the problems of young people: sedentary lifestyles, asociality.

One of the interaction types in the game is a reward for a certain overcome distance. At the beginning, players were given access to a new Pokemon for 1,500 steps taken, but over time the developers began to increase the distances, keeping players motivated with rewards. Now different amounts of additional items in the game are granted for passing 5, 25, and 50 kilometers per week. Players can cover significant distances, encouraging physical activity; Pokemons have become a kind of motivator for some people as well as the company during the walks, making them more interesting.

Despite the popularity of the video game and its advantages, the dangers and risks it carries 
should be noted. In particular, the threat to geographic information security, transportation and personal safety of consumers, because participants play in real terrain to catch the virtual cartoon characters on their smartphone screens. Pokemon Go has been blamed for traffic accidents, some of which were fatal because it had distracted players.
Nike introduced gamification when it launched Nike + , and today this program is a powerful media resource for athletes. With this app, the brand challenges users and encourages them to new achievements. Using the program, consumers can immediately see the covered distance, their speed and the number of burned calories. However, unlike other fitness programs, Nike + is a holistic social ecosystem.

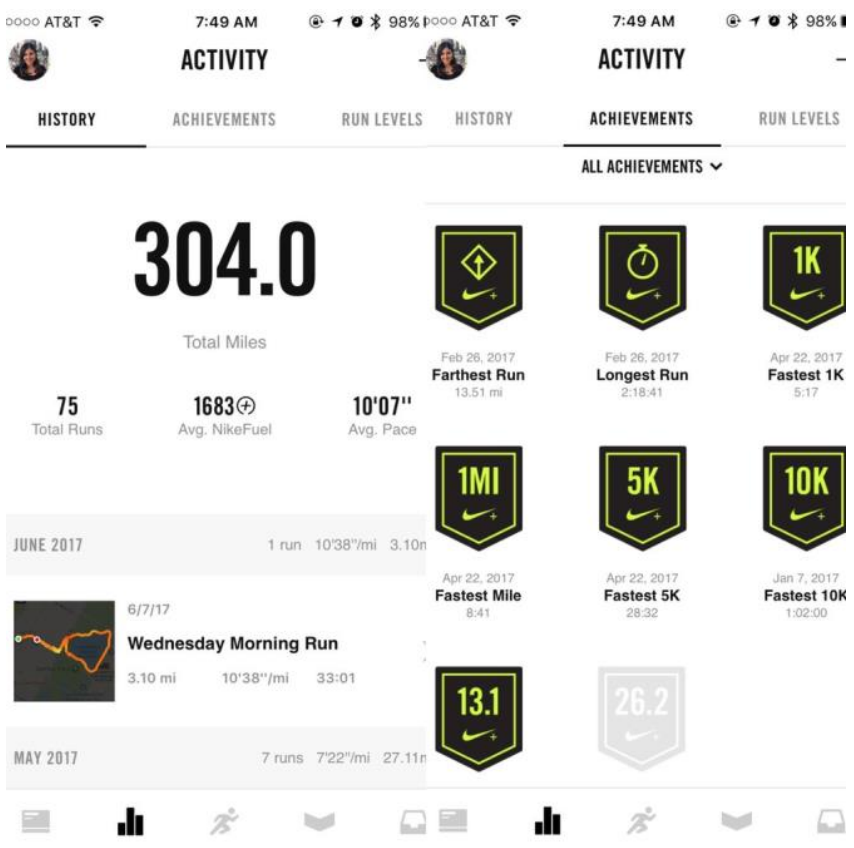

Fig. 6. Some of the available achievements in the NikeRunClub app (Nike +) / Photo: discussions.apple.com. URL: https://discussions.apple.com/welcome

The program ranks athletes by color marking from "yellow = beginner", to "black = professional". Each new level is more difficult to achieve, so that users do not lose motivation, various trophies and rewards for the number of workouts and their regularity are introduced.

The news of receiving awards can be shared with friends, and this causes a burst of enthusiasm due to the competition. In other words, Nike has managed to carry out an effective gamification with benefits for the health of the users.

In addition to the usual applications, programs for health maintenance involving virtual or augmented reality are also being created. Special VR-applications are aimed at providing psychological assistance to patients with burns, patients after ophthalmic surgery, etc. The gamified process calms people by drawing their attention to the interactive, distracting them from possible pain.

\section{Conclusions}

Nowadays gamification has a significant impact on the life of modern people. The market of gamified technologies is developing in Ukraine and in the world, because in this way a new audience is consistently attracted. Gaming technologies are implemented by companies of different areas to maintain the efficiency of their employees or to attract new customers. Motivation through gamification is becoming an effective way of interaction between corporations and ordinary people.

Gamification enables the rational use of available resources so that all parties achieve the goal as a result. However, it is also relevant to use gamified material with caution to avoid increasing competition or reducing the impact efficiency of interactive content.

Under such circumstances it is important to critically assess the role of game elements in 
each sphere, to realize and distinguish the useful potential of the game from playing as an end in itself, which can have a harmful effect on mental and physical health, on selfactualization in the society. The study of gamification application in various fields of activity, the boundaries of useful and harmful effects can be the subject of further research.

\section{Bibliographic References}

Bartle, R. (2004). Designing virtual worlds. New Riders, 741 p.

Bezchotnikova, A. O. (2016). Application of gamification to solve advertising and PR tasks. Bulletin of the European University. Social Communications Series, 16, pp. 8-18.

Clark, D. (2006). Games and e-learning. St. Peters Gate: Caspian Learning Ltd., 31 p.

Groh, F. (2012). Gamification: State of the Art Definition and Utilization: Paperpresented at the 4th Seminar on Research Trends in Media Informatics, Ulm, pp. 39-46.

Holovko, N. I. (2015). Game technologies as a means of activating students' cognitive activity. Bulletin of Taras Shevchenko University of Kyiv. Pedagogy series. 1(1), pp. 17-20.

Huotari, K., \& Hamari, J. (2012). Defining gamification: a service marketing perspective. In Proceedings of the 16th International Academic MindTrek Conference, October 3-5, Tampere, Finland: ACM, pp. 17-22.

Kapp, K. (2012). The gamification of learning and instruction: game-based methods and strategies for training and education. San Francisco: Pfeiffer, 336p.

Kim, A. (2010). Community building on the web: Secret strategies for successful online communitie. Addison-Wesley: Longman Publishing Co., 380 p.

Kostikova, I., Holubnycha, L., Shchokina, T., Soroka, N., Budianska, V., Marykivska, H.
(2019). A role-playing game as a means of effective professional english teaching. Amazonia Investiga, 8 (24), pp. 414-425. https://amazoniainvestiga.info/index.php/amaz onia/article/view/1001

Mostova, A. D. (2018). The concept of gamification and its role in marketing. European vector of economic development, 1 (24), pp. 96-106. DOI: https://doi.org/10.32342/2074-5362-2018-24-9 Nasyrova, S. (2019). Gamification as an effective tool for motivating staff of a modern organization. Scientific review, 3, pp. 6-16.

Pelling, N. (2019). The Short Prehistory of «Gamification. Funding Startups (\& Other Impossibilities). Nano Dome: website. URL: http://nanodome.wordpress.com/2011/08/09/th e-short-prehistory-of-gamification/

(14.09.2019).

Sánchez, V., Gómez, C., Ortiz, D., Clavijo, T., \& Váquiro, L. (2016). Social importance of english perception and inclusion of video games as a learning tool. Amazonia Investiga, 5(8), pp. 58-66.

https://amazoniainvestiga.info/index.php/amaz onia/article/view/703

Sereda, G. V. (2017). Gamification in Personnel Management: Foreign and Ukrainian Experience. Economics and organization of management, 4 (28), pp. 216-223.

Sergeeva, L. (2019). Gamification: game mechanics of staff motivation. Theory and methods of educational management. URL: http://umo.edu.ua/images/content/nashi_vydan ya/metod_upr_osvit/v_15/14.pdf (24.10.2019). Werbach, K., \& Hunter, D. (2012). For the win: how game thinking can revolutionize your business. Philadelphia: Wharton Digital Press, $148 \mathrm{p}$.

Zichermann, G. (2011). Game mechanics in web and mobile apps. California: O'Reilly Media, $182 \mathrm{p}$. 